\title{
HUBUNGAN KOMUNIKASI TERAPEUTIK DAN CARING DENGAN KEPUASAN PASIEN TERHADAP PERAWAT RUANG RAWAT INAP PENYAKIT DALAM RUMAH SAKIT UMUM MULTAZAM MEDIKA BEKASI TIMUR
}

\author{
*Rita Dwi Pratiwi, **Dida Siska Pertiwi \\ Program Studi S1 Keperawatan \\ STIKes Widya Dharma Husada Tangerang \\ Email: ritadwipratiwi@wdh.ac.id
}

\begin{abstract}
ABSTRAK
Komunikasi terapeutik merupakan komunikasi interpersonal yang dilakukan antara perawat dan petugas kesehatan lainnya dengan pasien yang berfokus pada kesembuhan pasien. Pelayanan professional oleh perawat dapat dilakukan oleh perawat dengan memperlihatkan perilaku caring. Komunikasi terapeutik dan caring akan memungkinkan terjadinya hubungan interpersonal yang harmonis antara perawat - klien dapat membantu dan memenuhi kebutuhan klien sehingga dapat memberikan kepuasan kepada klien. Penelitian ini bertujuan untuk mengetahui hubungan komunikasi terapeutik dengan kepuasan pasien dan untuk mengetahui hubungan caring dengan kepuasan pasien ruang rawat inap penyakit dalam RSU Multazam Medika Bekasi Timur. penelitian ini merupakan penelitian kuantitatif dengan desain cross sectional, jumlah sampel pada penelitian ini adalah 40 pasien dengan menggunakan teknik total sampling, instrument penelitian berupa kuesioner. Hasil bivariat dari uji statistic chi-squere diperoleh ada hubungan komunikasi terapeutik dengan kepuasan pasien dengan Ha1 diterimadan Hol ditolak dengan nilai $\mathrm{p}=0,005<\alpha=0$,05artinyaada hubungan yang signifikan antara komunikasi terapeutik dengan kepuasan pasien, sedangkan untuk hubungan caring dengan kepuasan pasien dengan Ha2 diterima dan Ho2 ditolak dengan nilai $\mathrm{p}=0,001<\alpha=0,05$ artinya ada hubungan yang signifikan antara caring dengan kepuasan pasien. Hasil multivariate dengan uji analisis regresi logistic antara variabel komunikasi terapeutik dan caring yang paling berpengaruh terhadap variabel kepuasan adalah caring dengan nilai sig 0,023 kekuatan hubungan dapat dilihat dari nilai $\mathrm{OR}=0,058$
\end{abstract}

Kata kunci : Komunikasi Terapeutik, Caring , Kepuasan Pasien Ruang Rawat Inap

Kepustakaan : 33 (2005-2017)

\begin{abstract}
Therapeutic communication is an interpersonal communication performed between nurses and other health care providers with patients which use focused on the patient's recovery. Professional services can be performed by nurses by showing caring behavior. Therapeutic and caring communication will allow for a harmonious interpersonal relationship between nurses - clients and also be able to help and meet client needs so as to provide satisfaction to clients. This study aims to determine the relationship of therapeutic communication with patient's satisfaction and to know the relationship of caring with patient satisfaction in RSU Multazam Medika Bekasi Timur. This research is a quantitative research with cross sectional design, the number of samples in this study was 40 patients using total sampling technique, research instrument in the form of questionnaire. The result of bivariate of chi-squere statistic test showed that there was correlation between therapeutic communication with patient's satisfaction with Hal accepted and Hol was rejected with $p=0,005<\alpha=0,05$ meaning that there was significant correlation between therapeutic communication with patient satisfaction, while for caring relationship with patient satisfaction with Ha2 accepted and Ho2 rejected with value $p=$ $0,001<\alpha=0,05$ meaning there was significant relation between caring with patient's satisfaction. Multivariate result with logistic regression analysis test between therapeutic communication and caring variable that most influence to satisfaction variable is caring with sig 0,023 strength of relation can be seen from $O R=0,058$
\end{abstract}

Keywords: Therapeutic Communication, Caring, Patient Satisfaction

Bibliography: 33 (2005-2017) 
PENDAHULUAN

Kepuasaan pasien ialah suatu tingkat perasaan pasien yang timbul sebagai akibat dari kinerja pelayanan kesehatan yang diperoleh setelah pasien membandingkannyadengan apa yang diharapkannya. Pasien baru akan merasa puas apabila kinerja pelayanan kesehatan yang diperolehnya sama atau melebihi dari apa yang menjadi harapannya dan sebaliknya, ketidakpuasaan akan timbul atau perasaan kecewa pasien akan terjadi apabila kinerja pelayanan kesehatan yang diperolehnya itu tidak sesuai dengan harapan nya. Salah satu faktor yang mempengaruhi kepuasan pasien adalah memberikan pelayanan dengan komunikasi yang terapeutik.Perawat yang memiliki keterampilan berkomunikasi secara terapeutik tidak saja akan menjalin hubungan rasa percaya pada pasien mencegah terjadinya masalah legal,memberikan kepuasan profesional dalam pelayanan keperawatan dan meningkatkan citra profesi keperawatan serta citra rumah sakit. Dengan demikian dapat dikatakan bahwa keperawatan melalui pelayanan asuhan keperawatan yang komprehensif sebagai indicator pelayanan dalam menentukan kepuasan klien serta tolak ukur mutu pelayanan (Gilles 1978 dalam Meyer \& Pallas,2010)
Beberapa penelitian telah membuktikan bahwa ternyata di beberapa rumah sakit, perilaku caring perawat masih rendah. Berdasarkan penelitian yang dilakukan oleh agustin (2002) di RS Dr. Mohammad Hosein Palembang, menyebutkan bahwa hampir separuh perawat $(48,5 \%)$ dinilai tidak caring.

Ruang rawat inap penyakit dalam di Rumah Sakit Umum Multazam Medika Bekasi Timur terdiri dari 2 ruang yaitu ruang Mekkah dan Madinah.Ruang mekkah terdiri dari 15 orang perawat dan ruang madinah terdiri dari 15 orang perawat.Hasil dari studi pendahuluan terhadap 8 orang pasien diruang rawat inap penyakit dalam dikatakan bahwasebagian perawat sering menjawab dengan jawaban ketusketika pasien melontarkan pertanyaan kepada perawat. Selain itu 3 orang pasien mengatakan bahwa perawat diruang penyakit dalam kurang ramah dan galak.

Tujuan Penelitian dalam penelitian ini untuk mengetahui hubungan komunikasi terapeutik dan caring dengan kepuasan pasien terhadap perawat Ruang Rawat Inap Penyakit Dalam RumahSakit Umum Multazam Medika Bekasi Timur.

Seorang perawat harus memiliki caring dalam pelayanannya terhadap 
pasien, karena hubungan antara pemberi pelayanan kesehatan dengan pasien merupakan faktor yang mempengaruhi proses kepuasan dan kesembuhan pasien tersebut. Elemen kepuasan konsumen sebenarnya merupakan yang terpenting, jika konsumen (pasien) tidak puas dengan layanan yang diberikan, dia tidak akan mencari layanan itu atau menerimanya. Walaupun layanan tersebut tersedia, mudah di dapat, dan mudah di jangkau. Oleh karena itu, mutu layanan yang ditawarkan merupakan hal penting dalam layanan kesehatan. Namun, mutu layanan harus berasal dari perspektif konsumen, karena mutu layanan merupakan jasa yang diterima oleh konsumen layanan tersebut (Watson 2007, dalam Nursalam,2011:215) (Al- Assaf,2009)

\section{METODE PENELITIAN}

Desain penelitian ini merupkan penelitian kuantitatif dengan menggunakan desain penelitian deskriptif analitik dengan studi pendekatan cross sectional. Penelitian cross sectional adalah jenis penelitian yang menganalisa variabel independen dan variabel dependen pada periode sama atau pada suatu waktu yang sama (Azrul dan Prihatno, 2014). Dengan melihat bagaimana komunikasi terapeutik dan caring dengan kepuasan pasien pada perawat di Rumah Sakit Umum Multazam Medika Bekasi Timur. Observasi atau pengumpulan data yang dilakukan sekaligus pada suatu dimana subjek penelitian hanya observasi sekali saja dan pengukuran nya dilakukan terhadap status karakter atau variabel subjek pada saat pemeriksaan (Notoadmodjo, 2012 Fhebby Maesafitri 2016) metode ini menggunakan kuesioner.

Tempat penelitian dilaksanakan di Ruang Rawat Inap Penyakit Dalam di Rumah Sakit Umum Multazam Medika Bekasi Timur tahun 2018.

Populasi adalah wilayah generalisasi yang terdiri atas objek yang mempunyai kuantitas dan karakteristik tertentu yang ditetapkan oleh peneliti untuk dipelajari kemudian ditarik kesimpulannya (Sugiono,2016. Populasi dalam penelitian ini adalah semua pasien Ruang Rawat Inap Penyakit Dalam RSU Multazam Medika Bekasi Timuryang berjumlah 40 orang.

Pada penelitian ini sampel yang diambil sampel yang memenuhi kriteria inklusi. Pada pengambilan sampel penelitian ini menggunakan metode nonprobability sampling yaitu pengambilan sampel bukan secara acak yang tidak didasarkan atas kemungkinan yang dapat diperhitungkan. Teknik 
pengambilan sampel dalam penelitian ini menggunakan total sampling yaitu pengumpulan sampel dengan mengambil seluruh anggota populasi sebagai responden dan sampel. Sampel diambil dari pasien yang dirawat Ruang Rawat Inap Penyakit Dalam Rumah Sakit Umum Multazam Medika Bekasi Timur dengan target keseluruhan responden 40 orang. Kriteria inklusi dalam penelitian ini adalah pasien yang diRawat Inap di Ruang Penyakit Dalam RSU Multazam Medika Bekasi Timur, pasien yang diRawat Inap minimal 3 x 24 jam dan bersedia menjadi responden.

\section{HASIL PENELITIAN}

\section{ANALISA UNIVARIAT}

Analisa univariat ini menjelaskan dengan distribusi frekuensi responden berupa jenis kelamin, pendidikan, pekerjaan, umur di Ruang Rawat Inap Penyakit Dalam Rumah Sakit Umum Multazam Medika Bekasi Timur a. Umur

Diagram 5.1

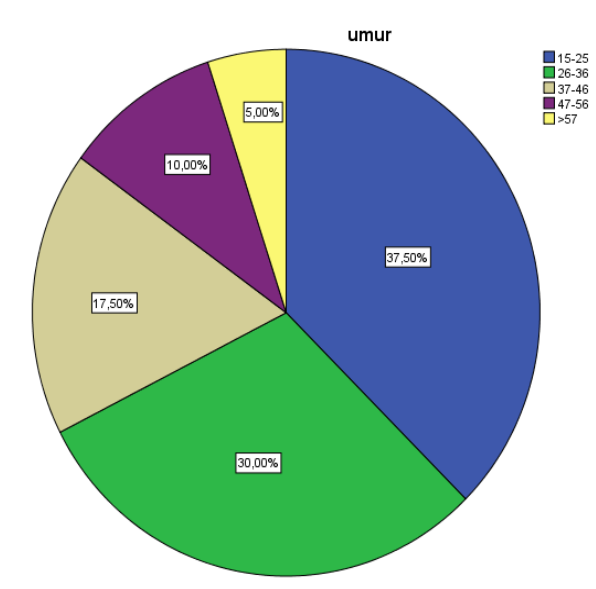

Berdasarkan diagram 5.1 menunjukan bahwa nilai frekuensi menurut umur responden sebanyak 40 orang responden. Usia 15-25 tahun sebanyak 15 responden sebesar (37,5\%), lanjut usia 26-36 tahun sebanyak 12 responden sebesar $(30,0 \%)$, usia 37-46 tahun sebanyak 7 responden sebesar (17,5\%), usia 47-56 tahun sebanyak 4 responden sebesar $(10,0 \%)$ dan usia > 57 tahun sebanyak 2 responden sebesar (5,0\%).Kelompok umur 20-30 tahun adalah umur produktif, pada umur ini klien akan lebih banyak bertanya dan akan lebih kritis apabila pelayanan yang diterima tidak sesuai yang diharapkan. Sehingga akan mempengaruhi tingkat kepuasan klien (Bahahudin, Suhendri, Anugrah 2009). 
b. Jenis Kelamin

Diagram 5.2

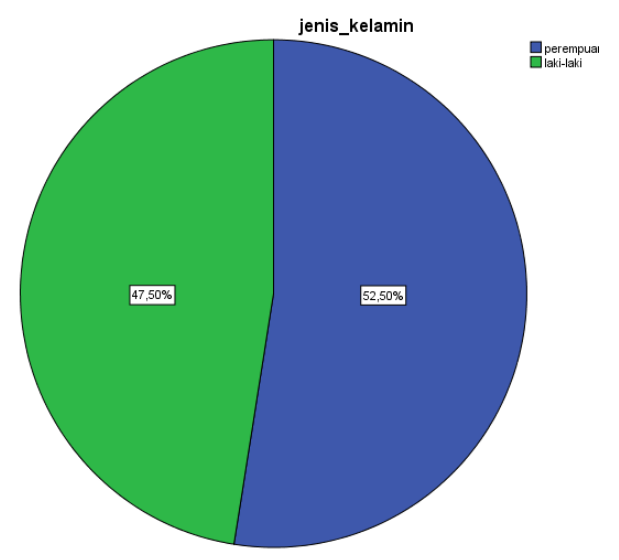

Berdasarkan diagram 5.2 menunjukan bahwa nilai frekuensi jenis kelamin perempuan sebanyak 21 responden sebesar $(52,5 \%)$ dan Laki-laki sebanyak 19 responden sebesar (47,5\%).Jenis kelamin pria lebih agresif dalam mengungkapkan ketidaknyamanan perbedaan prilaku antara pria dan wanita karena disebabkan oleh perbedaan struktur, hormon-hormon dan tumbuh kembang otak.Otak pria mempunyai karakteristik agresif dan kompetitif (Bahahudin, Suhendri, Anugrah 2009).Hasil penelitian ini diperkuat oleh penelitian sebelumnya yang dilakukan (Herlina Pratiwi dkk 2010) didapatkan hasil analisa uji suatu hubungan antara karkteristik jenis kelamin wanita mempunyai tingkat kepuasan lebih besar dari pada pria sebesar $(68,8 \%)$ c. Pendidikan

Diagram 5.3

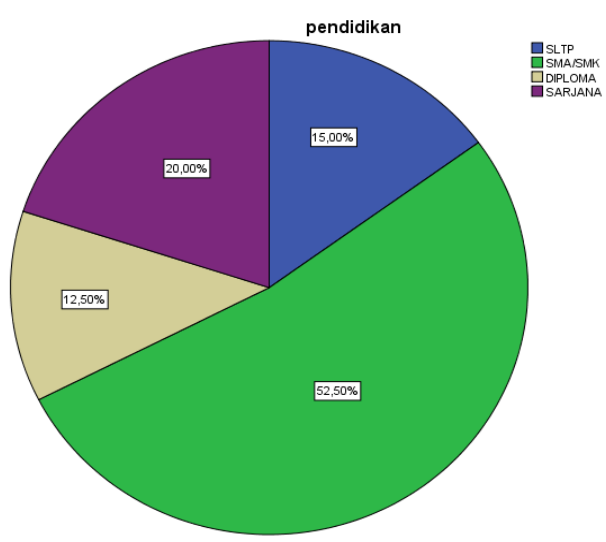

Berdasarkan diagram

menunjukan bahwa nilai frekuensi tingkat pendidikan dari 40 responden dengan berbagai tingkat pendidikan. SLTP sebanyak 6 responden dengan persentase sebesar (15,0\%), SMA/SMK sebanyak 21 responden dengan persentase sebesar (52,5\%), Diploma sebanyak 5 responden dengan persentase sebesar $(12,5 \%)$, dan Sarjana sebanyak 8 responden dengan persentase sebesar (20,0\%).Tingkat pendidikan sebagian besar diploma dan sarjana yang lebih berfikir ilmiah dan rasional sehingga akan lebih kritis jika tidak sesuai dengan yang diharapkan (Bahahudin, Suhendri, Anugrah 2009). Hasil penelitian ini diperkuat oleh penelitian sebelumnya yang dilakukan (Herlina Pratiwi, dkk 2010) didapatkan hasil analisa uji suatu hubungan antara karkteristik dengan tingkat pendidikan 
SLTA mempunyai tingkat kepuasan sebesar $(68,5 \%)$

d. Komunikasi Terapeutik

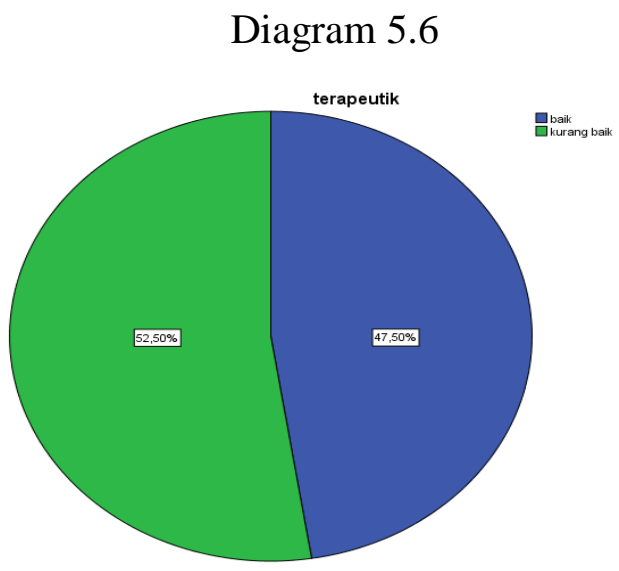

Berdasarkan diagram 5.6 menunjukan bahwa nilai frekuensi komunikasi terapeutik pada perawat dari 40 responden dengan komunikasi terapeutik perawat baik sebanyak 19 responden dengan persentase sebesar (47,5\%), dan dengan komunikasi terapeutik perawat kurang baik sebanyak 21 responden dengan persentase $\quad(52,5 \%)$. Komunikasi terapeutik dapat meningkatkan hubungan yang konstruktif antara perawat danklien jika konsumen merasakan kinerja yang tinggi maka konsumen akan mengalami kepuasan (Junaidi,2008). Komunikasi terapeutik merupakan suatu interaksi interpersonal antara perawat dan klien yang selama berinteraksi langsung perawat berfokus kepada kebutuhan khusus klien untuk meningkatkan pertukaran informasi yang efektif antara perawat dank klien
(Videbeck,2008). Hasil penelitian ini diperkuat oleh penelitian sebelumnya yang dilakukan (Herlina Pratiwi,dkk 2010) didapatkan data bahwa 31 klien sebagai responden variabel komunikasi terapeutik didapatkan 18 klien $(58,1 \%)$ menyatakan komunikasi terapeutik perawat baik dan 13 klien $(41,9 \%)$ menyatakan komunikasi terapeutik perawat kurang baik dalam berinteraksi dengan klien saat memberikan asuhan keperawatan.

\section{e. Caring}

\section{Diagram 5.7}

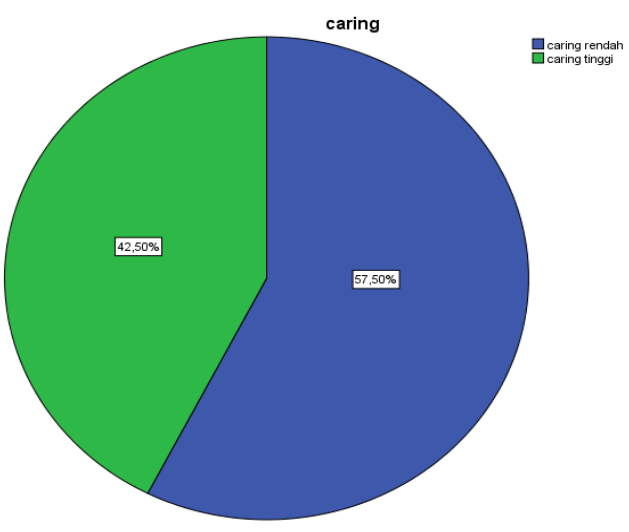

Berdasarkan diagram 5.7 menunjukan bahwa nilai frekuensi caring perawat dari 40 responden dengan caring perawat rendah sebanyak 23 responden dengan persentase sebesar $(57,5 \%)$, dan dengan caring perawat tinggi sebanyak 17 responden dengan persentase sebesar (42,5\%).Perawat adalah orang yang menjadi salah satu kunci dalam memenuhi kepuasan pasien oleh karena itu perilaku caring perawat dapat memberikan pengaruh dalam pelayanan yang 
berkualitas kepada pasien (Prompahakul,et al, 2011). Hasil penelitian ini diperkuat oleh penelitian sebelumnya yang dilakukan ( Panji Pratama Putra, 2011) menunjukan bahwa perilaku caring perawat dengan kategori tinggi yaitu sebanyak 9 responden $(27,3 \%)$ sedangkan responden yang paling banyak menilai perilaku caring perawat rendah sebanyak $23(69.7 \%)$ responden.

f. Kepuasan pasien

\section{Diagram 5.8}

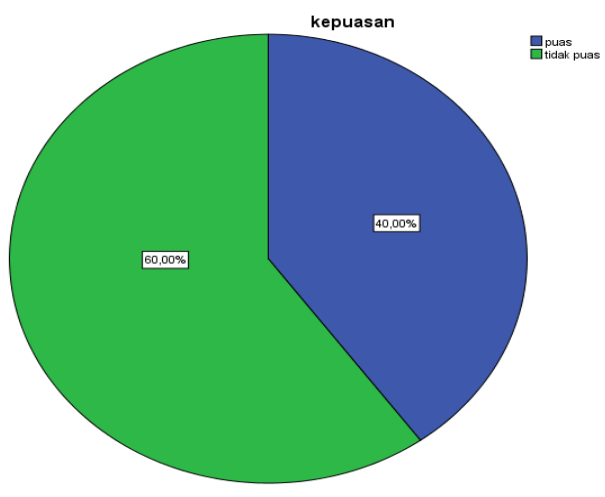

Berdasarkan diagram 5.8 menunjukan bahwa nilai frekuensi kepuasan pasien pada perawat dari 40 responden. Puas sebanyak 16 responden dengan persentase sebesar $(40,0 \%)$ dan tidak puas sebanyak 23 responden dengan persentase sebesar $(60,0 \%) . K e p u a s a n$ pasien merupakan nilai subyektif pasien terhadap pelayanan yang diberikan setelah membandingkan dari hasil pelayanan yang diberikan dengan harapannya (Khairul Anwar 2017).Hasil penelitian ini diperkuat oleh penelitian sebelumnya yang dilakukan( Nancy
Febriana , 2009) menunjukan bahwa kepuasan pasien dengan kategori tidak puas sebanyak $19(63,11 \%)$ responden. Sedangkan pada kepuasan pasien dengan kategori puas sebanyak $23 \quad(54,8 \%)$ responden

\section{ANALISA BIVARIAT}

a. Hubungan antara komunikasi terapeutik dengan kepuasan pasien pada perawat ruang rawat inap penyakit dalam RSU Multazam Medika Bekasi Timur.

Hasil uji statistik analisa hubungan antara komunikasi terapeutik dengan kepuasan pasien di peroleh nilai $\mathrm{P}$-value $=0,005<$ $\alpha=0,05$ dengan kekuatan korelasi sedang yang artinya korelasi bermakna dapat disimpulkan bahwa Ho ditolak artinya ada Hubungan Antara Komunikasi Terapeutik Dengan Kepuasan Pasien Ruang Rawat Inap Penyakit Dalam Rumah Sakit Umum Multazam Medika Bekasi Timur. Berdasarkan tabel 5.1 hasil crosstabulation komunikasi terapeutik dengan kepuasan pasien pada perawat di ruang rawat inap penyakit dalam hasil analisa diperoleh yang mengalami puas dan komunikasi terapeutik baik sebanyak 12 responden dengan persentase sebesar $(30,0 \%)$ dan sebanyak 4 responden $(10,0 \%)$ 
mempunyai komunikasi terapeutik kurang baik. Sedangkan yang tidak puas dan mempunyai komunikasi terapeutik baik sebanyak 7 responden (17,5\%), serta sebanyak 17 responden (42,5\%) mempunyai komunikasi terapeutik kurang baik.

Hasil penelitian diatas memberikan gambaran bahwa komunikasi terapeutik dapat dilihat dari kemampuan perawat dalam menjalin suatu hubungan komunikasi berdasarkan kebutuhan klien dengan memperhatikan teknik- teknik komunikasi verbal dan non verbal(Isacs 2007).Fortnish and Worret (2008) juga mengemukakan perilaku verbal dan nonverbal, seperti sikap, kepercayaan, dan perasaan merupakan bagian dari komunikasi dang sangat dibutuhkan untuk komunikasi terapeutik dan terdapat tujuh sifat dalam mengefektifkan komunikasi terapeutik dan sifat ini sangat dibutuhkan untuk menjalin hubungan perawat-klien. Teori (Supranto 2007) mendefisinikan kepuasan sebagai tingkat perasaan seseorang setelah membandingkan kinerja atau hasil yang dirasakannya dengan harapannya.Tingkat kepuasan merupakan fungsi dari perbedaan antara kinerja yang dirasakan dengan harapan. Apabila kinerja dibawah harapan, maka pelanggan akan sangat kecewa, bila kinerja sesuai harapan, maka pelanggan akan sangat puas. Penelitian ini juga didukung oleh teori (Moison, Walter dan White 2006 dalam Khairul Anwar,2017) yang menyatakan bahwa salah satu faktor yang mempengaruhi kepuasan pasien adalah faktor komunikasi yaitu tata cara komunikasi yang diberikan pihak penyedia jasa dan bagaimana keluhan-keluhan pasien dengan cepat diterima dan ditangani oleh penyedia jasa terutama perawat dalam memberikan bantuan terhadap keluhan pasien.

Hasil penelitian ini diperkuat oleh penelitian sebelumnya yang dilakukan oleh (Herlina Pratiwi, dkk pada tahun 2010) di RS Bunda Margonda Depok tentang hubungan komunikasi terapeutik perawat dengan tingkat kepuasan pasien.Dalam penelitian tersebut disimpulkan bahwa terdapat hubungan yang bermakna antara komunikasi terapeutik perawat dengan tingkat kepuasan klien.Hasil penelitian ini juga didukung oleh penelitian sebelumnya yang dilakukan oleh (PentiSari Ningsih2015) di RS PKU Muhammadiyah Yogyakarta Unit II tentang hubungan komunikasi terapeutik perawat dengan tingkat kepuasan pasien 
rawat inap. Dalam penelitian tersebut disimpulkan bahwa terdapat hubungan yang bermakna antara komunkasi terapeutik perawat dengan tingkat kepuasan klien

b. Hubungan antara caring dengan kepuasan pasien pada perawat ruang rawat inap penyakit dalam RSU Multazam Medika Bekasi Timur.

Hasil uji statistik analisa hubungan antara caring perawat dengan kepuasan

pasien diperoleh nilai $\mathrm{P}$-value $=$ $0,001<\alpha=0,05$ dengan kekuatan korelasi sangat lemah yang artinya korelasi bermakna dapat disimpulkan bahwa Ho ditolak artinya ada Hubungan Antara Caring Dengan Kepuasan Pasien Ruang Rawat Inap Penyakit Dalam Rumah Sakit Umum Multazam Medika Bekasi Timur. Berdasarkan tabel 5.2 hasil crosstabulation caring dengan kepuasan pasien pada perawat di ruang rawat inap penyakit dalam hasil analisa diperoleh yang mengalami puas dan mempunyai caring tinggi sebanyak 12 responden dengan persentase $(30,0 \%)$, dan sebanyak 4 responden dengan persentase $(10,0 \%)$ mempunyai caring rendah. Sedangkan yang tidak puas dan mempunyai caring tinggi sebanyak 5 responden dengan persentase $(12,5 \%)$. Serta sebanyak 19 responden $(47,5 \%)$ mempunyai caring rendah.

Teori Potter dan Perry (2009) menyebutkan caring sebagai suatu cara pemeliharaan berhubungan dengan menghargai orang lain, disertai perasaan memiliki dan bertanggung jawab. Caring adalah fenomena universal yang mempengaruhi cara manusia berfikir, merasa, dan mempunyai hubungan dengan sesama. Perilaku caring perawat sangat mempengaruhi kepuasan pasien, apabila pelayanan yang diberikan sudah sesuai dengan kebutuhan pasien dan diberikan dengan cara yang ramah pada waktu mereka dirawat sesuai sumber daya yang dimiliki, maka pasien akan merasakan kepuasan yang tinggi. Hal ini didukung oleh teori (Pohan 2007) yang menyatakan bahwa kualitas pelayanan kesehatan memiliki pengaruh terhadap frekuensi tingkat kepuasan pasien semakin baik kualitas pelayanan kesehatan maka semakin baik pula frekuensi tingkat kepuasan pasien, 
Hasil penelitian ini diperkuat oleh penelitian sebelumnya yang dilakukan oleh (Eka Puspitasari 2012) di RS PKU Muhammadiyah Yogyakarta tentang hubungan perilaku caring perawat dengan kepuasan pasien rawat inap. Didapatkan nilai caring perawat yang menjawab baik sebanyak 12 pasien $(40 \%)$ dan caring perawat cukup baik sebanyak 2 pasien $(6,7 \%)$ menilai caring perawat kurang baik. Hasil penelitian menunjukan bahwa $\mathrm{P}$ lebih kecil dari pada $0,05 \quad(0,023<0,05)$ sehingga dapat disimpulkan bahwa ada hubungan yang bermakna antara hubungan perilaku caring perawat dengan tingkat kepuasan pasien rawat inap di RS PKU Muhammadiyah Yogyakarta.

Hasil penelitian ini juga didukung oleh penelitian sebelumnya yang dilakukan oleh (AA.Komp Ngurah Darmawan 2012) di RSUD Klungkung Bali tentang hubungan perilaku caring perawat dengan tingkat kepuasan pasien rawat inap didapatkan nilai yang berprilaku tidak caring sebanyak 61 responden dengan persentase $(48 \%)$ dan yang berperilaku caring sebanyak 65 responden dengan persentase (52\%).
Hasil penelitian menunjukan bahwa nilai P- value sebesar 0,001 ( $\mathrm{p}<0,05)$ yang berarti ada hubungan yang signifikan antara perilaku caring perawat dengan kepuasan pasien diruang rawat inap RSUD Klungkung Bali.

Hasil penelitian ini semakin didukung juga oleh penelitian sebelumnya yang dilakukan ( Ummi Kalsum 2016) di RSUP Fatmawati tentang hubungan perilaku caring perawat dengan kepuasan pasien diruang perawatan teratai hasil analisa diperoleh $(68,2 \%)$ pasien merasa tidak puas terhadap pelayanan caring perawat, sedangkan $(25,4 \%)$ merasa puas terhadap pelayanan caring perawat. Dari hasil statistik diperoleh nilai $\mathrm{p}=0,001$ sehingga dapat disimpulkan bahwa hubungan caring perawat sangat berpengaruh terhadap tingkat kepuasan pasien

c. Hubungan umur dengan komunikasi terapeutik

Hasil analisis menunjukan pada tabel 5.3 menunjukan bahwa berdasarkan umur dengan komunikasi terapeutik didapatkan nilai $\mathrm{p}$-value $=$ $0,732<\alpha=0,05$ yaitu Ho diterima, dapat disimpulkan bahwatidak ada hubungan yang signifikan antara umur dengan komunikasi terapeutik karena 
di penelitian ini ada faktor lain yang mempengaruhi kepuasan pasien yaitu caring dan komunikasi terapeutik.Hasil penelitian ini sejalan dengan penelitian sebelumnya yang dilakukan oleh (Zidni Imanurohman 2016) tentang hubungan antara komunikasi terapeutik dengan tingkat kepuasan pasien menunjukan bahwa nilai $\mathrm{p}$-value $=0,308$ yang artinya bahwa tidak ada hubungan yang signifikan antara umur dengan komunikasi terapeutik.

d. Hubungan umur dengan Caring

Hasil analisis menunjukan dapat dilihat pada tabel 5.4 menunjukan bahwa berdasarkan umur dengan komunikasi terapeutik didapatkan nilai p-value $=0,808$ dapat disimpulkan bahwa tidak ada hubungan yang signifikan antara umur dengan caring perawat. Berdasrkan tabel 5.4 hasil crosstabulation umur dengan caring di ruang rawat inap penyakit dalam Berdasarkan tabel 5.4 menunjukan bahwa nilai frekuensi berdasarkan umur dengan caring kategori rendah yaitu umur (15-25 tahun) sebanyak 8 (20,0\%) responden dan kategori tinggi $7(17,5 \%)$ responden dengan total 15 responden dan persentase sebesar (37,5\%), (26-36 tahun) kategori rendah sebanyak $9(22,5 \%)$ responden dan kategori tinggi $3(7,5 \%)$ responden dengan total 12 responden dan persentase sebesar $(30,0 \%)$, (37-46 tahun) kategori rendah sebanyak $3(7,5 \%)$ responden dan kategori tinggi sebanyak 4(10,0\%) responden dengan total $7(17,5 \%)$ responden, (47-56 tahun) kategori rendah sebanyak 2 $(5,0 \%)$ responden dan kategori tinggi sebanyak $2(5,0 \%)$ responden total 4 responden dengan persentase sebesar (10,0\%), (>57 tahun) kategori rendah sebanyak $1(2,5 \%)$ orang dan kategori tinggi sebanyak $1(2,5 \%)$ orang dengan total 2 dan persentase sebesar $(5,0 \%)$ jadi dapat disimpulkan bahwa Ho diterima dengan nilai $\mathrm{p}$-value $=0,808$ $<\alpha=0,05$ yang artinya tidak ada hubungan yang signifikan antara umur dengan caring

Hasil penelitian ini sejalan dengan penelitian sebelumnya yang dilakukan oleh (Rahmad Gurusinga 2013 ) tentang perilaku caring perawat dengan kepuasan pasien rawat inap diketahui bahwa umur $<35$ tahun sebanyak $69(50,7 \%)$ caring perawat rendah. Sedangkan umur $>35$ tahun sebanyak $67(49,3 \%)$ caring perawat tinggi. Didapatkan nilai $\mathrm{p}$-value = 0,615 yang artinya tidak ada hubungan 
yang signifikan antara umur dengan caring

e. Hubungan umur dengan kepuasan pasien

Hasil analisis menunjukan dapat dilihat pada tabel 5.9 menunjukan bahwa

berdasarkan umur dengan kepuasan pasiendidapatkan nilai $\mathrm{p}$-value $=0,319$ yang artinya tidak ada hubungan yang signifikan. Berdasarkan tabel 5.9 hasil crosstabulationumur dengan kepuasan pasiendidapatkan bahwa.Berdasarkan tabel 5.9 menunjukan bahwa nilai frekuensi berdasarkan umur dengan kepuasan pasien kategori puas yaitu umur (15-25 tahun) sebanyak $8(20,0 \%)$ responden dan kategori tidak puas sebanyak $7(17,5 \%)$ responden dengan total 15 responden dan persentase sebesar (37,5\%), (26-36 tahun) sebanyak $4(10,0 \%)$ responden kategori puas dan sebanyak $8(20,0 \%)$ responden kategori tidak puas dengan total 12 responden dan persentase sebesar (30,0\%), (37-46 tahun) sebanyak $1(2,5 \%)$ responden kategori puas dan sebanyak $6 \quad(15,0 \%)$ responden kategori tidak puas dengan total 7 responden dan persentase sebesar (17,5\%), (47-56 tahun) sebanyak $2(5,0 \%)$ responden kategori puas dan sebanyak $2(5,0 \%)$ responden kategori tidak puas dengan total 4 responden dan persentase sebesar (10,0\%), (>57tahun) sebanyak 1 $(2,5 \%)$ responden kategori puas dan sebanyak $1(2,5 \%)$ responden kategori tidak puas dengan total 2 responden dan persentase sebesar $(5,0 \%)$ jadi dapat disimpulkan bahwa Ho diterima dengan nilai $\mathrm{p}$-value $=0,319<\alpha=$ 0,05yang artinya tidak ada hubungan yang signifikan antara umur dengan kepuasan.

Hasil penelitian ini sejalan dengan penelitian yag dilakukan oleh (Herlina Pratiwi dkk 2010) didapatkan karakteristik klien umur dengan tingkat kepuasan kelompok umur < 30 tahun, 30-60 tahun dan > 30 tahun memiliki tingkat kepuasan lebih besar dari pada umur > 30 tahun sebesar $55.6 \%$ didapatkan nilai $\mathrm{p}$ - value $=$ 0,736 yang artinya tidak ada hubungan yang signifikan antara umur dengan kepuasan pasien

f. Hubungan jenis kelamin dengan komunikasi terapeutik

Hasil analisis menunjukan dapat dilihat pada tabel 5.5 menunjukan bahwa berdasarkan jenis kelamin dengan komunikasi terapeutik didapatkan nilai $\mathrm{p}$-value $=0,988$ yang 
artinya tidak ada hubungan yang signifikan. Berdasarkan tabel 5.5 hasil crosstabulation jenis kelamin dengan komunikasi terapeutik didapatkan bahwa komunikasi terapeutik baik dengan jenis kelamin perempuan sebanyak $10(25,0 \%)$ dan kurang baik sebanyak 11 (27,5\%), sedangkan jenis kelamin laki laki kategori baik sebanyak 9 (22,5\%) dan kurang baik sebanyak $10(25,0 \%)$ jadi dapat disimpulkan bahwa Ho diterima dengan nilai $\mathrm{p}$-value $=0,988<\alpha=0,05$ yang artinya tidak ada hubungan yang signifikan antara jenis kelamin dengan komunikasi terapeutik

Hasil penelitian ini sejalan dengan penelitian sebelumnya yang dilakukan oleh (Rhisa Oviani 2016). Didapatkan bahwa jenis kelamin perempuan komunikasi terapeutik kurang baik sebesar $(22,14 \%)$ dan tidak baik sebesar $(17,4 \%)$. Sedangkan jenis kelamin laki-laki baik sebesar $(34,28 \%)$ dan kurang baik sebesar $(26,42 \%)$ didapatkan nilai p-value $=0,619$ yang artinya tidak ada hubungan yang signifikan antara jenis kelamin dengan komunikasi terapeutik

g. Hubungan jenis kelamin dengan caring perawat
Hasil analisis menunjukan dapat dilihat pada tabel 5.7 menunjukan bahwa berdasarkan jenis kelamin dengan caring perawat didapatkan nilai $\mathrm{p}$ - value $=0,565$ yang artinya tidak ada hubungan yang signifikan dengan faktor jenis kelamin dengan caring perawat dan bertolak belakang dengan teori. Berdasarkan tabel 5.7 hasil crosstabulation jenis kelamin dengan caring perawat menunjukan bahwa caring kategori rendah dengan jenis kelamin perempuan sebanyak 13 $(32,5 \%)$ responden dan kategori tinggi sebanyak $8(20,0 \%)$ responden dengan total 21 responden dan persentase sebesar (52,5\%). Sedangkan untuk caring kategori rendah dengan jenis kelamin laki-laki sebanyak $10(25,0 \%)$ responden, dan kategori tinngi sebanyak $9(22,5 \%)$ respoonden dengan total 17 dan persentase sebesar $(42,5 \%)$ jadi dapat disimpulkan bahwa Ho diterima dengan nilai $\mathrm{p}$ value $=0,988<\alpha=0,05$ yang artinya tidak ada hubungan yang signifikan jenis kelmin dengan caring

Hasil penelitian ini sejalan dengan penelitian sebelumnya yang dilakukan oleh ( Yani Indrastuti 2010) didapatkan bahwa periaku caring kurangdengan jenis kelamin perempuan sebanyak 33 
$(82,5 \%)$ dan caring baik dengan jenis kelamin perempuan sebanyak 7 $(17,5 \%)$ didapatkan nilai $\mathrm{p}$-value $=$ 0,823 yang artinya tidak ada hubungan yang signifikan antara jenis kelamin dengan caring.

h. Hubungan jenis kelamin dengan kepuasan pasien

Hasil analisis menunjukan dapat dilihat pada tabel 5.10 menunjukan bahwa berdasarkan jenis kelamin dengan kepuasan pasien didapatkan nilai $\mathrm{p}$ - value $=0,313$ yang artinya tidak ada hubungan yang signifikan dengan faktor jenis kelamin dengan kepuasan pasien dan bertolak belakang dengan teori. Berdasarkan tabel 5.10 hasil crosstabulation jenis kelamin dengan kepuasan pasien menunjukan bahwa kepuasan pasien kategori puas dengan jenis kelamin perempuan sebanyak $10(25,0 \%)$ dan kategori tidak puas sebanyak 11 (27,5\%), sedangkan untuk kepuasan pasien kategori puas berjenis kelamin lakilaki sebanyak $6(15,0 \%)$ dan kategori tidak puas sebanyak $13(32,5 \%)$ jadi dapat disimpulkan bahwa Ho diterima dengan nilai $\mathrm{p}$-value $=0,313<\alpha=0,05$ yang artinya tidak ada hubungan yang signifikan antara jenis kelamin dengan kepuasan.
Hasil penelitian ini sejalan dengan penelitian sebelumnya yang dilakukan oleh (Mahendro kusuma 2010) didapatkan bahwa dengan jenis kelamin perempuan sebanyak 15 $(10,7 \%)$ kategori puas, dan sebanyak 4 $(2,9 \%)$ kategori tidak puas. Sedangkan dengan jenis kelamin perempuan kategori puas sebanyak $9(3,15 \%)$, dan kategori puas sebanyak 11 (7,9\%) didapatkan nilai $\mathrm{p}$-value $=0,585$ yang artinya tidak ada hubungan yang signifikan antara jenis kelamin dengan kepuasan pasien

i. Hubungan pendidikan dengan komunikasi terapeutik

Hasil analisis menunjukan dapat dilihat pada tabel 5.7 menunjukan bahwa berdasarkan pendidikan dengan komunikasi terapeutik didapatkan nilai $\mathrm{p}$ - value $=0,363$ yang artinya tidak ada hubungan yang signifikan dengan faktor pendidikan dengan komunikasi terapeutik dan bertolak belakang dengan teori. Berdasarkan tabel 5.7 hasil crosstabulation menunjukan bahwa nilai frekuensi berdasarkan pendidikan dengan komunikasi terapeutik kategori baik yaitu pendidkam SLTP sebanyak 3 $(7,5 \%)$ responden dan kurang baik 3 $(7,5 \%)$ responden dengan total 6 
responden dan persentase sebesar ( 15,0\%). SMA/SMK sebanyak 8 (20,0\%) responden kategori baik dan kategori kurang baik sebanyak 13 ( $32,5 \%)$ dengan total $21 \quad(52,5 \%)$ responden. Diploma sebanyak 3 $(7,5 \%)$ responden kategori baik dan kategori kurang baik sebanyak 2 $(5,0 \%)$ responden dengan total 5 $(12,5 \%)$ responden. Sarjana sebanyak $5(12,5 \%)$ kategori baik dan kurang baik sebanyak $3(7,5 \%)$ dengan total 8 responden $(20,0 \%)$ jadi dapat disimpulkan bahwa Ho diterima dengan nilai $\mathrm{p}$-value $=0,363<\alpha=0,05$ yang artinya tidak ada hubungan yang signifikan antara pendidikan dengan komunikasi terapeutik

Hasil penelitian ini sejalan dengan penelitian sebelumnya yang dilakukan (Fairuz Ali 2012) didapatkan bahwa kommunikasi terapeutik baik berpendidikan SMP (14,6\%), SMA/SMK komunikasi terapeutik baik $(12,5 \%)$ dan sarjana komunikasi terapeutik kurang baik (72,9\%) didapatkan nilai $\mathrm{p}$-value $=0,377$ yang artinya tidak ada hubungan yang signifikan antara pendidikan dengan komunikasi terapeutik

j. Hubungan pendidikan dengan caring
Hasil analisis menunjukan dapat dilihat pada tabel 5.8 menunjukan bahwa berdasarkan pendidikan dengan caring didapatkan nilai $\mathrm{p}$ - value $=$ 0,644 yang artinya tidak ada hubungan yang signifikan dengan faktor pendidikan dengan caring dan bertolak belakang dengan teori. Berdasarkan tabel 5.8 hasil crosstabulation menunjukan bahwa nilai frekuensi berdasarkan pendidikan dengan caring kategori rendah yaitu pendidkam SLTP sebanyak $3(7,5 \%)$ responden dan kategori tinggi $3(7,5 \%)$ responden dengan total 6 responden dan persentase sebesar $(15,0 \%)$. SMA/SMK sebanyak $12 \quad(30,0 \%)$ responden kategori rendah dan kategori tinggi sebanyak 9 ( 22,5\%) dengan total $21(52,5 \%)$ responden. Diploma sebanyak 3 (7,5\%) responden kategori rendah dan kategori tinggi sebanyak $2(5,0 \%)$ responden dengan total $5(12,5 \%)$ responden. Sarjana sebanyak $5(12,5 \%)$ kategori rendah dan tinggi sebanyak 3 (7,5\%) dengan total 8 responden $(20,0 \%)$ jadi dapat disimpulkan bahwa Ho diterima dengan nilai $\mathrm{p}$-value $=0,644<\alpha=0,05$ yang artinya tidak ada hubungan yang signifikan antara pendidikan dengan caring 
Hasil penelitian ini sejalan dengan penelitian sebelumnya yang dilakukan oleh ( Lilis Johratun 2017) didapatkan bahwa kategori caring baik $(72,7 \%)$ berpendidikan SMP, sedangkan SMA caring kategori caring rendah $(6,1 \%)$ dan S1 caring rendah $(21,2 \%)$ didapatkan bahwa nilai $\mathrm{p}$-value = 0,843 yang artinya tidak ada hubungan yang signifikan antara caring dengan pendidikan

k. Hubungan pendidikan dengan kepuasan

Hasil analisis menunjukan dapat dilihat pada tabel 5.11 menunjukan bahwa berdasarkan pendidikan dengan kepuasan pasien didapatkan nilai $\mathrm{p}$ value $=0,674$ yang artinya tidak ada hubungan yang signifikan dengan faktor pendidikan dengan kepuasan pasien dan bertolak belakang dengan teori. Berdasarkan tabel 5.11 hasil crosstabulation menunjukan bahwa nilai frekuensi berdasarkan pendidikan dengan kepuasan pasienkategori puas yaitu pendidkam SLTP sebanyak 3 (7,5\%) responden dan kategori tidak puas $3(7,5 \%)$ responden dengan total 6 responden dan persentase sebesar (15,0\%). SMA/SMK sebanyak 7 $(17,5 \%)$ responden kategori puas dan kategori tidak puas sebanyak 14 (
$35,0 \%)$ dengan total $21(52,5 \%)$ responden. Diploma sebanyak 1 $(2,5 \%)$ responden kategori puas dan kategori tidak puas sebanyak

$4(10,0 \%)$ responden dengan total 5 $(12,5 \%)$ responden. Sarjana sebanyak $5(12,5 \%)$ kategori puas dan tidak puas sebanyak $3(7,5 \%)$ dengan total 8 responden $(20,0 \%)$ jadi dapat disimpulkan bahwa Ho diterima dengan nilai $\mathrm{p}$-value $=0,674<\alpha=0,05$ yang artinya tidak ada hubungan yang signifikan antara pendidikan dengan kepuasan.

Hasil penelitian ini sejalan dengan penelitian sebelumnya yang dilakukan oleh ( Puspa Sari 2012) menunjukan bahwa kategori puas dengan pendidikan SD $(13,3 \%)$ kategori cukup (20,0\%), SMP kategori puas $(13,3 \%)$ kategori kurang (13,3\%), SMA kategori puas $(6,7 \%)$ kategori cukup ( $16,7 \%)$ dan sarjana kategori puas $(3,3 \%)$ dan kategori cukup (13,3\%) didapatkan nilai $\mathrm{p}$-value $=0,636$ yang artinya bahwa tidak ada hubungan yang signifikan antara pendidikan dengan kepuasan pasien

\section{Analisa Multivariat}

Analisis multivariat dalam penelitian ini menggunakan uji regresi logistik 


\begin{abstract}
Berdasarkan tabel $\quad 5.1$ menunjukan bahwa dari kedua variabel yaitu variabel komunikasi terapeutik dan caring yang paling berpengaruh terhadap variabel kepuasan pasien adalah caring dengan nilai sig $=0,023$ dan kekuatan hubungan dapat dilihat dari nilai $(\mathrm{OR}=$ $0,58)$
\end{abstract}

Berdasarkan hasil tersebut, dapat disimpulkan bahwa semakin baik perilaku caring perawat dalam memberikan pelayanan keperawatan kepada pasien maka tingkat kepuasan pasien terhadap pelayanan keperawatan akan semakin baik juga perilaku caring perawat sangat penting dalam memenuhi kepuasan dan caring sangat berpengaruh menjadi salah satu indikator kulaitas pelayanan disebuah rumah sakit. Perilaku caring perawat akan berpengaruh terhadap kepuasan pasien, perilaku caring perawat yang baik akan menjadikan kepuasan pasien kearah postif, karena pasien memiliki kepercayaan yang tinggi dalam menilai pelayanan rumah sakit. Sehingga berdampak pada kunjungan ulang pasien dan rasa percaya terhadap rumah sakit tetapi untuk pasien yang menilai perilaku caring perawat cukup dan kurang akan membuat kepuasan menyimpang menjadi kearah negativ. (Dwidiyanti,2008)

Perawat merupakan ujung tombak dari pelayanan kesehatan dirumah sakit dan merupakan orang yang paling lama berinteraksi dengan pasien, sehingga dalam menjalankan praktik keperawatan perlu lebih memperhatikan perilaku caring perawat sebagai salah satu upaya untuk memberikan pelayanan keperawatan yang berkualitas yang pada akhirnya memberikan kepuasan kepada pasien (Rahmad Gurusinga, 2013) .

Hasil penelitian ini didukung oleh penelitian sebelumnya yang dilakukan oleh (Charles B. Turangan dkk pada tahun 2015) di RSUP Prof.Dr.R.D Kandou Manado tentang analisis faktor- faktor yang berhubungan dengan kepuasan pasien di instalasi rawat inap. Hasil analisis regresi logistik menunjukan bahwa perhatian caring perawat memiliki nilai sig 0,032 dan nilai $\mathrm{OR}=3,567$ hal ini berarti bahwa perhatian caring perawat berpengaruh terhadap kepuasan pasien di instalasi rawat inap. 


\section{A. Hambatan Penelitian}

Hambatan penelitian yang peneliti alami yaitu peneliti tidak mendapatkan hambatan pada saat pengambilan data, tetapi peneliti merasa kesulitan pada saat pengolahan data di SPSS dan membutuhkan waktu sekitar satu minggu untuk mempelajari lebih jelas tentang pengolahan data di SPSS.

\section{KESIMPULAN DAN SARAN}

\section{A. Kesimpulan}

Berdasarkan hasil penelitian ini maka dapat diambil kesimpulan sebagai berikut :

1. Gambaran karakteristik responden berdasarkan umur 15-25 tahun responden sebanyak 15 responden dengan persentase sebesar $(37,5 \%)$ dengan tingkat pendidikan terakhir SMA/SMK sebanyak 21 responden dengan persentase sebesar (52,5\%), dan pekerjaan wiraswasta sebanyak 16 responden dengan persentase sebesar $(40,0 \%)$ dengan jenis kelamin perempuan sebanyak 21 responden dengan persentase sebesar $(52,5 \%)$
2. Gambaran komunikasi terapeutik perawat ruang rawat inap penyakit dalam RSU Multazam Medika Bekasi Timur dengan kategori kurang baik sebanyak 21 responden dengan persentase sebesar $(52,5 \%)$

3. Gambaran caring perawat ruang rawat inap penyakit dalam RSU Multazam Medika Bekasi Timur kategori caring rendah sebanyak 23 responden dengan persentase sebesar $(57,5 \%)$

4. Gambaran kepuasan pasien ruang rawat inap penyakit dalam RSU Multazam Medika Bekasi Timur kategori tidak puas sebanyak 24 responden dengan persentase sebesar $(60,0 \%)$

5. Ada hubungan antara komunikasi terapeutik dengan kepuasan pasien di peroleh nilai $\mathrm{P}$-value $=0,005<\alpha=0,05$ dengan kekuatan korelasi sedang yang artinya korelasi bermakna, yang dapat disimpulkan bahwa dalam penelitian ini Hal diterima artinya ada hubungan yang 
signifikan anntara komunikasi terapeutik dengan kepuasan pasien Ruang Rawat Inap Penyakit Dalam Rumah Sakit Umum Multazam Medika Bekasi Timur.

6. Ada hubungan antara caring dengan kepuasan pasien di peroleh nilai $\mathrm{P}$-value $=0,001<$ $\alpha=0,05$ dengan kekuatan korelasi sangat lemah yang artinya korelasi bermakna, dan dapat disimpulkan bahwa $\mathrm{Ha} 2$ diterima artinya ada hubungan yang signifikanantara caring dengan kepuasan pasien Ruang Rawat Inap Penyakit Dalam Rumah Sakit Umum Multazam Medika Bekasi Timur

7. Ada pengaruh caring terhadap variabel kepuasan pasien kekuatan hubungan dapat dilihat dari nilai sig 0,023 dan nilai $\mathrm{OR}=0,058$. Sedangkan untuk komunikasi terapeutik nilai sig 0,781 dan nilai $\mathrm{OR}=$ 1,360

\section{B. Saran}

Sesuai hasil kesimpulan tersebut, maka penulis mengajukan beberapa saran. Saran yang dapat diberikan adalah sebagai berikut :

1. Institutisi Pendidikan

Ilmu pengetahuan tentang komunikasi terapeutik dan caring perawat dalam memberikan asuhan keperawatan hendaknya lebih diperdalam

dengan cara menambah praktek di ruang laboratorium maka dapat diterapkan dalam kehidupan sehari-hari. Dilingkungan pendidikan komunikasi terapeutik dan caring perawat merupakan ciri khas profesi keperawatan sehingga setelah lulus dari institusi pendidikan mahasiswa berkompeten dalam berkomunikasi secara terapeutik dan menerapkan perilaku caring nantinya dimasa yang akan datang.

2. Pelayanan Kesehatan

a. Rumah sakit selaku institusi pelayanan kesehatan hendaknya membuat kebijakan dalam mengontrol dan mengevaluasi perawat untuk senantiasa 
menerapkan komunikasi terapeutik dan perilaku caring secara konsisten dan terpadu sesuai dengan standar dalam memberikan pelayanan asuhan keperawatan sehingga dapat meningkatkan mutu pelayanan dirumah sakit

b. Kepala ruangan unit keperawatan ruang penyakit dalam hendaknya menyususn rencana kegiatan pelatihan komunikasi terapeutik dan perilaku caring secara rutin terhadap perawat guna meningkatkan kompetensi perawat dalam hal komunikasi terapeutik dan perilaku caring

3. Penelitian selanjutnya

Bagi peneliti selanjutnya diharapkan untuk melakukan penelitian dengan jumlah sampel yang lebih serta, desain penelitian yang berbeda dan lebih memfokuskan kepada penerapan komunikasi terapeutik dan perilaku caring serta faktor-faktor lainnya yang mempengaruhi tingkat

kepuasan pasien selama
dirawat

\section{DAFTAR PUSTAKA}

Buku :

Abdul Nasir, Abdul Muhith, Sajidin, Wahitiqbal Mubarak . 2011 Komunikasi Dalam Keperawatan Teori Dan Aplikasi. Salemba Medika Jakarta

Dahlan, Sopiyudin, M. 2016. Statistik Untuk Kedokteran Dan Kesehatan. Seri 1 Edisi 6.Epidemiologi Indonesia Jakarta

Nursalam .2011 .Proses Dan Dokumentasi Keperawatan, Konsep Dan Praktek . Jakarta Salemba Medika

Nursalam. 2014. Manajemen Keperawatan Aplikasi dalam Praktik Keperawatan Profesional Edisi 4. Jakarta Salemba Medika

Potter, Perry .2005 . Buku Ajar Fundamental Keperawatan Konsep Proses dan Praktik .Jakarta :Erlangga

Simamora . 2012. Buku Ajar Manajemen Keperawatan. Jakarta : EGC

Sugiyono. 2016. Metode Penelitian Kuantitatif Kualitatif Dan $R \& D$. Alfabeta Bandung

Suryani. 2016. Komunikasi Terapeutik :Teori Dan Praktik, ED.2. Kedokteran EGC Jakarta

Wulan Kencana Hastuti . 2011 Pengantar Etika Keperawatan. PT Prestasi Pusat karaya Jakarta 
Jurnal :

Abdullah Samina, Kousar Robina, Azhar ,Waqas Ali . 2017 .Nurse's And Patient's Perception Regarding Nurse Caring Behaviors And Patients Satisfaction .

Akhmawardani Luvi, Sukesi Niken, Kusuma Bayu Argo. 2012 .Hubungan Komunikasi Terapeutik Perawat Dengan Tingkat Kepuasan Pasien.

Anwar Khairul .2017 .Hubungan Komunikasi Terapeutik Perawat Dengan Kepuasan Pasien

Departemen Kesehatan Republik Indonesia .2005 .Keputusan Menteri Kesehatan Republik Indonesia Tentang Registrasi Dan Praktik Perawat

Darmawan Ngurah Komp.AA. 2012. Hubungan Perilaku Caring Perawat Dengan Tingkat Kepuasan Pasien

Febriana Nancy .2009 . Pengaruh Nursing Round Terhadap Kepuasan Pasien

Gurusinga Rahmad. 2013. Perilaku Caring Perawat Dan Kepuasan Pasien

Hery Retno . 2012 Hubungan Komunikasi Terapeutik Dengan Tingkat Kepuasan Pasien Post Operasi

Ikafah, Harniah .2017. Perilaku Caring Perawat Dengan Kepuasan Pasien

Imelda . 2015. Hubungan Antara Mutu Pelayanan Keperawatan Degan Kepuasan Pasien
Joharotun Lilis. 2017. Hubungan Pelayanan Komunikasi Terapeutik Perawat Dengan Tingkat Kepuasan Pasien

Kalsum Ummi .2016 .Hubungan Perilaku Caring Perawat Dengan Kepuasan Pasien

Kusuma Prasetyo Mahendro, Hastuti .2011.Pengaruh Komunikasi Terapeutik Perawat Terhadap Kepuasan Pasien Rawat Jalan.

Lubis Imanurohman Zidni .2016 .Hubungan Antara Komunikasi Terapeutik Dengan Tingkat Kepuasan Pasien .

Oviani Rhisa .2016 .Pengaruh Komunikasi Terapeutik Perawat Terhadap Kepuasan Pasien

Pratiwi Herlina, Abdilah Husni, Huda Akmal Ihsan, Supriatin Titin. 2010. Hubungan Komunikasi Terapeutik Perawat Dengan Tingkat Kepuasan Klien

Purwasari Triani .2015 . Hubungan Komunikasi Perawat Dengan Kepuasan Pasien di Ruang Rawat Inap.

Putra Pratama Panji .2011 .Hubungan Perilaku Caring Perawat Dengan Tingkat Kepuasan Pasien .

Puspitasari Eka. 2012. Hubungan Perilaku Caring Perawat Dengan Tingkat Kepuasan Pasien Rawat Inap

Respati Diane Rurry .2012 .Studi Diskriptif Perilaku Caring Perawat 
Sari Puspa .2015. Gambaran Pelaksanaan Komunikasi Terapeutik Oleh Perawat Pelaksana Pada Pasien

Santi Fauziah Nura'ini .2017 .Hubungan Mutu Pelayanan Kesehatan Dengan Tingkat Kepuasan Pasien

Turangan Charles B. dkk. 2015. Analisis Faktor-Faktor yang Berhubungan Dengan Kepuasan Pasien

Zulphiyana Siti, Indrayana Sofyan .2015 .Komunikasi Terapeutik Perawat Berhubungan Dengan Kepuasan Pasien 